\title{
VENEREAL DISEASE IN THE MERCANTILE MARINE
}

\section{Discussion}

DR. WANSEY BAyLy said he had been much interested in hearing of the difficulties experienced in treating venereal disease in the Mercantile Marine. He once served for a year in the Royal Mail Steam Packet Company, and for the same length of time during the War in the Navy; and his conclusion was that it was very difficult to treat sailors at sea efficiently for venereal affections. The majority of those who "go down to the sea in ships " were of the strong, virile type, men who would not be dissuaded from satisfying their sexual instinct. The important thing, in his view, was to prevent their acquiring venereal disease. Mr. Cuthbert Laws, Managing Director of the Shipping Federation, was at one time a member of the Executive Committee of the Society for the Prevention of Venereal Disease, which the speaker represented, and he agreed with the Shipping Federation that prevention was better than cure. Their experience, and the speaker's own, was that the sailor was a very intelligent fellow, and that he readily imbibed any information imparted to him regarding the prevention of venereal disease, also that, in the majority of cases, he could be relied upon to carry out such instructions as were given him.

The Shipping Federation asked the speaker to write a lecture for them, one which could be distributed among seamen, specially pointing out the symptoms of venereal disease, the serious results following such infection, and the method of prevention by immediate self-disinfection. This pamphlet told the simple truths as to the importance of cleanliness and prompt disinfection of the person when risk had been run. It was pointed out that after immediate self-disinfection the risk of infection was very greatly reduced, although not entirely eliminated.

In I926 the International Labour Office of the League 
of Nations issued a report on "The Protection of the Health of Seamen against Venereal Disease," containing recommendations of a joint commission consisting of five representatives of shipowners, five representatives of seamen and two members of the governing body. This commission recommended that the circular published by the British Shipping Federation should be forwarded to various shipowners and seamen's organisations in which the adoption of the following measures in regard to disinfection were proposed :-

(I) The dissemination amongst seamen of exact knowledge of the prevention and cure of venereal diseases. (With this object the Shipping Federation stated in its circular that it would " be prepared to supply suitable literature for gratuitous distribution among seamen, including a lecture specially written for seamen " by the speaker.)

(2) The distribution, at cost price, to seamen of the requisite materials for prevention by immediate selfdisinfection.

The report also recorded that Australia, Belgium, Czecho-Slovakia, France, Germany, Poland, Sweden had taken steps in regard to the prevention of venereal disease on board ship.

In the Proceedings of the Imperial Social Hygiene Congress of 1925, printed by H.M. Stationery Office, it is stated that Surgeon-Commander T. B. Shaw, R.N., representing the Admiralty, said: "The part played by suitable and immediate prophylaxis is no longer disputed by any responsible person, and our only hope of eventually exterminating venereal disease altogether is by the wider application of this measure," and he proceeded to say that " on the African Station they issued during a period of eighteen months fourteen hundred preventive outfits, that during that time they had a certain amount of venereal disease, though only one of the men to whom the packets had been issued got the disease. I quite agree with Sir Leonard Rogers (Government of India) as to the importance of prophylaxis in our hope of eventually exterminating venereal disease."

At St. Lucia one out of several ships which visited that highly infected port taught its sailors disinfection, and there were only four cases on the ship as a result of putting in there, whereas on other ships, on which pro- 


\section{BRITISH JOURNAL OF VENEREAL DISEASES}

phylaxis was not taught and disinfectants were not provided, there were very numerous cases of venereal disease.

He felt that if such teaching and the provision of means of disinfection were supplied, venereal disease in both the Mercantile Marine and the Navy would reach vanishing point.

DR. Morgan (Medical Secretary of the Joint Advisory Committee of the Board of Trade and Ministry of Health) said that the Board of Trade recently appointed a Committee to revise the scales of drugs and medical appliances required to be carried by various classes of ships, and that Committee had paid particular attention to equipment more or less suitable for treatment of venereal disease on board ship. The "Ship Captain's Medical Guide," for the use of captains who had not a surgeon on board, had also been revised, and the equipment had been brought into unison with that revision. Even now, however, the equipment for treatment of this disease was not altogether satisfactory, and the advice on this subject had been revised in consultation with Colonel Harrison, of the Ministry of Health. These revisions would shortly be published. The same committee would shortly be proceeding to revise medical scales for ships which carried surgeons, and he was sure that this committee would be grateful to anybody who would send suggestions and recommendations both as to equipment and modus operandi for the ships' surgeons.

Mr. John AdAms said that what Dr. Ross said about chancroids interested him greatly; Liverpool, according to what that gentleman said, seemed to be almost the home of chancroids ; in London cases of the kind were but rarely seen; at the clinic he attended such a case had not been seen for years. When, fifty years ago, he was at St. Bartholomew's Hospital, one saw four or five cases of chancroid to one of syphilis. What was the reason of the change ?

Cases of venereal disease had to be treated on board ship ; there was inadequate preparation for the purpose. $\mathrm{He}$ frequently had post-graduates at his clinic, and the opportunities given to medical men to learn how to treat cases of venereal disease were very small. The class stood round and saw the senior assistant, or the senior surgeon, administer the remedy, but that was not enough ; the medical man who was learning should, under supervi- 
sion, be taught to give the treatment himself. Only this would give confidence, a very essential thing. It was not an easy matter to give intravenous injections at first. There was always the fear of making a mistake. He told such men in difficult cases to follow out Colonel Harrison's plan and give intramuscular injections. If syphilis was to be cured, it must be done in the first two years from the date of infection; otherwise, patients could not be healthy citizens; they would still have a positive Wassermann. Much the same could be said about the treatment of gonorrhœa.

Colonel HARRISON said that the papers by Dr. Hanschell and Dr. Ross, as also the remarks by Dr. John Adams, confirmed the opinion which he had held for a long time that the regular treatment of a man of the Mercantile Marine suffering from V.D. could be secured only by his remaining ashore. Dr. Ross had shown by the fact that his programme of treatment of syphilis in a seaman was compressed that he would not really put any trust in any treatment which the patient might receive whilst afloat. It seemed to him (the speaker) rather hard that a seaman should have to remain ashore so long, and he thought the remedy lay not only in ships being better equipped in material for the modern treatment of V.D., but in ships' doctors being better trained to use this equipment. Whatever might be thought about the practicability of continuing afloat treatment commenced ashore, there was no escaping the necessity of accurate diagnosis and skilled treatment of men whose V.D. commenced on the voyage. His own experience led him to believe that this was by no means always satisfactory, and he could endorse what had been said by Dr. Ross as to the frequency with which sores had been treated with lotio nigra, or other antiseptics, before microscopical diagnosis had been made. He was particularly glad, therefore, to support Dr. Hanschell's suggestion to take advantage of the numbers of candidates for the post of ship's doctor by insisting on these previously undergoing a post-graduate course of instruction in the Modern Diagnosis and Treatment of V.D.

Mr. Jones (National Union of Seamen) said that, from the layman's point of view, what was most desired was prevention of venereal disease. This could best be brought about by cleansing the ports where seamen con- 


\section{BRITISH JOURNAL OF VENEREAL DISEASES}

gregated. The body he represented were giving attention to that matter.

The Rev. G. F. Dempster (British Sailors' Society) remarked that if he were able to make any real contribution to the main purpose of this medical society he would be happy, but he feared he could not do so.

$\mathrm{He}$ believed that the secret of any success which would be achieved, beyond that already attained, would be by way of securing the confidence of the men. Several speakers had referred to the equipment and qualifications of surgeons on board ship, but these gentlemen, like members of the crew, were not permanent units; they were constantly changing. Unless the surgeons were very keen about their work and were able to get the confidence of the men, and record the facts, he did not think much improvement was likely to result. Seamen were not essentially different from landsmen, though their calling might make them appear so. And they were infected ashore. This aspect would have to be tackled keenly before much advance could result. Dr. Ross mentioned several ports as dangerous ones for V.D., but he omitted to name some of the worst. Many of the persons who infected sailors in London were women who came from Continental ports. These people must some day be dealt with. It would be seen how serious was the menace when he said that persons known to him had rendezvous not only in the East End of London, but in the West End too. Thus, in all probability, the same infected source was operating in West London as in Dockland. He did not see why some of the subjects touched on to-night should be specially applied to seafarers, except that seamen becoming infected in one port carried their infection to another port, and so they constituted travelling dangers, and for that reason perhaps they ought to be specially treated. He reiterated his contention that the medical gentlemen treating these seamen must get their confidence. One of the things which militated against this confidence was officialdom. As a padre, he much objected to ordered religious parades. In the same way, he felt that there was a barrier between the man who needed medical attention and the medical man who was treating him when there was an official attitude taken up. For success there must be a friendly, confidential, close intercourse. Sailormen, like other men, if they felt their 


\section{VENEREAL DISEASE IN MERCANTILE MARINE}

doctor was a " pal," would show a greater readiness to avail themselves of the services of the V.D. clinic, the practitioner, or the ship surgeon. $\mathrm{He}$ was recently struck by seeing the difference in the attitude of two surgeons who were practising. One of them was really putting up a mental barrier between himself and the patients, while the other was winning the confidence of those with whom he was dealing, and this latter method not only resulted in better following up, but in many cases the patients resolved to abstain from such risks in future.

Commander Cavill, R.N.R., expressed the thanks of a sailor to this Society for all it was doing for the welfare of the seaman. He had been astounded at the voluntary efforts made on behalf of the British seaman. Shipowners took a keen interest in this venereal trouble. Eight years ago he and his colleagues started an intensive campaign, based primarily on prevention, but not much progress was made. What was needed was the education of the layman up to the required standard. Directors of companies were written to, but largely the response was that it was a subject people ought not to discuss.

With regard to special treatment for seamen ashore, when a seaman was away from his ship he was an ordinary person, and he intermingled with ordinary folk, and the speaker considered it was wrong to establish special clinics for seamen. He could not imagine a seaman going to a clinic for venereal disease close to the dock gates; he would rather blend with other people attending a clinic further afield.

Dr. Ross appeared to think that accommodation for seamen on board British ships was not so good as that on ships of some other countries, but the speaker did not subscribe to that view.

The PREsIdent said that a number of things had impressed him in the present discussion. One was that seamen were now freely using the treatment centres provided for these diseases near the docks. Despite what Commander Cavill said, he, with others who had to deal with this subject, believed that if one did not provide treatment close to the docks one would not get the proper proportion of seamen going to them.

Another thing was, that apparently some of the V.D. centres were conducted in such a manner that they did 


\section{BRITISH JOURNAL OF VENEREAL DISEASES}

secure the confidence of seamen, the latter feeling that they were being properly and kindly treated, and so they continued with the treatment and followed the advice given them in a remarkably faithful manner.

It had been said more than once this evening that the only effective way of treating syphilitic seamen was to treat them ashore, and, while he thought there was much truth in that at present, he hoped that in future the provision for treatment on board ship would do away with the necessity of men being kept on shore for this purpose. A glimmering of hope in that regard was given by Dr. Hanschell's suggestion that it should be a condition of employment as ship's doctor on a liner that there shall have been adequate training in the modern treatment of venereal diseases. During the period of waiting, such men could obtain instruction in the matter at a V.D. clinic. Then members of the crew having venereal disease need not be kept too long off their work. Even Dr. Ross might feel less hesitation in those circumstances about allowing men to take the return voyage.

Mrs. Neville Rolfe (British Social Hygiene Council) said she had been waiting for answers to two questions which were very prominent in this mercantile problem.

One was as to what medical provision could be made for the man engaged in the extensive coast-wise trade and the fishing and other non-passenger-carrying boats, particularly those calling at such smaller ports as possessed no clinic, Fowey and Lowestoft, for instance. A large number of men so engaged were absent from home for long periods, and so were under much the same conditions as commercial travellers, who were well known to be great spreaders of venereal disease in the civil population. These coasting men exposed themselves to the risk of infection.

She was also anxious to know the extent to which those in charge of the large seamen's clinics at ports found that the Belgian Agreement was working so far as foreign seamen were concerned. Also, was there any difficulty about inducing British seamen to visit foreign clinics in the ports they called at? In other words, was the feeling of want of confidence in foreign clinics being overcome?

DR. HANSChell, in reply, said that on this matter 226 
each could really speak only as to his own particular port. The Port of London extended for many miles, from Teddington to Tilbury. The portion of this of which he had experience comprised three docks close together, about six miles down-stream from London Bridge. The ships coming into those docks belonged mostly to wellknown lines, carried surgeons, and were manned usually by a crew that signed on the same ship each voyage : all of which no doubt accounted for his view being rosier than that set out by Dr. Ross for Liverpool. The landsman he saw was the docker-longshoreman, who in many cases had been to sea or would go to sea, often went to the same places of amusement as the seaman, and often had cohabited with the same prostitutes. He too had found chancroid very frequent in Asiatics. It was acquired abroad. Asiatics from the ships' crews had no prostitute supply apparently in London as yet. So far as he could gather from interpreters, this was mainly because the Asiatics had not enough money for London. There were three difficulties to be overcome or to be lessened : the first was to find the best treatment in the shortest time which would render the patient noninfective; the second was how to provide sufficient facilities on shore and at sea for giving treatment promptly and continuously; the third, and most formidable of all, was how so to change ways of thinking, and thus ways of conduct, that exposure to the chance of infection with V.D. on the part of the seafarer would become less of a habit.

DR. Ross, in reply, said he did not believe chancroid was a Liverpool disease ; it was a disease of foreign ports, and belonged to dockside areas. Two clinics out of five in Liverpool saw chancroids. These were the clinics most attended by seamen. Chancroid was more common abroad.

With regard to adopting the non-official attitude in clinics, he agreed that for clinics to be popular the doctor must be a friend to the patients, and if surgeons waiting for a ship billet were to attend clinics, they would learn how to handle these cases successfully.

Some foreign ports were good. At Bordeaux the medical officer in charge allowed sailors to attend at the same time as he was giving female patients treatment. At Bremen there did not appear to be a V.D. clinic, and the 


\section{BRITISH JOURNAL OF VENEREAL, DISEASES}

men were passed on to a practitioner by the British Consul, and that doctor attended the cases at little charge over the cost of the drugs. Form V 44 was not used much, but he often received with the men letters giving the needed details. 